\title{
ANALISIS PENGARUH ASPEK KEPERILAKUAN TERHADAP SISTEM AKUNTANSI (STUDI KASUS PADA PT. SINAR GALESONG PRIMA DI MANADO)
}

\author{
Wulan Mogontha ${ }^{1}$ Grace B Nangoi $^{2}$, Natalia Gerungai ${ }^{3}$ \\ ${ }^{1,2,3}$ Fakultas Ekonomi dan Bisnis Jurusan Akuntansi, Universitas Sam Ratulangi Manado, Jl Kampus Bahu \\ Manado, 95115, Indonesia \\ Email :Wulanmogontha2@gmail.com
}

\begin{abstract}
Accounting is information or, to be specific, accounting system. Accounting System has important role in a company where the success of an accounting system depends on the human behavior as respond giving user. Therefore, there should be a necessary consideration regarding behavioral aspect in running an accounting system whereas be behavioral accounting is focusing on accountant's and auditor's decision making wether the system is run according to the company's procedure and their objective as well. This research is aimed to analize the effect of behavioral aspect on accounting system run by PT Sinar Galesong Prima in Manado as a trading company. The method of analysis applied is multiple linear regression. The result of the conducted research shows that behavioral aspect (Attitude, Motivation, Perseption, Emotion) is not significantly affected the accounting system run by the company. It is expected that the company would give more concern, particularly to the behavioral aspect in applying the existing system so that in the future, the accounting system in the company could run effectively and efficiently according to the company's objective.
\end{abstract}

Keywords : Accounting System, Behavioral Accounting, Attitude, Motivation, Perpseption, Emotion.

\section{PENDAHULUAN}

Sistem akuntansi adalah kumpulan sumberdaya, seperti manusia dan peralatan, yang diatur untuk mengubah data menjadi informasi. Informasi ini dikomunikasikan kepada beragam pengambil keputusan. Saat ini, digital dan informasi online semakin digunakan dalam sistem akuntansi. Organisasi perlu menempatkan sistem ini di depan, dan mempertimbangkan baik segi sistem ataupun manusia sebagai faktor yang terkait ketika mengatur sistem akuntansi. Sebuah sistem akuntansi tidak lepas dari sumber daya manusia yang dimana berperan untuk menjalankan sistem akuntansi tersebut walaupun secara teknis telah di nilai baik dan didukung kemajuan teknologi canggih, kesalahan dalam menempatkan sumber daya manusia dapat menyebabkan kesalahan pada output yang di hasilkan atau diharapkan. Oleh karena itu perlu adanya pertimbangan aspek keperilakuan terhadap mendesain, menganalisis dan mengimplementasi dalam menjalankan sistem akuntansi.

PT. Sinar Galesong Prima di Manado yakni perusahaan dagang yang bergerak dibidang otomotif atau transportasi pada perusahaan ini elemen sistem akuntansi merupakan komponen utama karena di setiap aktifitasnya pasti melibatkan pergerakan output dan mengelolah input. Berdasarkan hal tersebut maka sistem informasi akuntansi yang diterapkan haruslah efektif dan efisien serta memiliki unsur pengendalian yang memadai agar menghindari terjadinya kecurangan. Terlepas dari sistem akuntansi yang dijalankan, unsur perilaku yakni psikologi sosiologi dan psikologi sosial khususnya sikap, motivasi, persepsi dan emosi karyawan yang ada pada perusahaan tersebut berkaitan dengan jalannya sistem akuntansi dirasa perlu untuk diteliti pengaruhnya, dimana dari hasil observasi lapangan sewaktu penulis studi magang diperusahaan ini penulis masih melihat beberapa kekurangan 
dalam aspek keperilakuan yang berada pada karyawan-karyawan disana contohnya seperti aspek sikap, motivasi dalam bekerja dan emosi karyawan pada perusahaan tersebut yang belum bisa dikatakan baik dalam menjalankan sebuah sistem akuntansi untuk perusahaan tersebut masih adapun beberapa kekurangan lain terkait aspek keperilakuan yang masih perlu penulis teliti lebih jauh lagi. Tujuan dari penelitian yang dilakukan peneliti adalah untuk menganalisis aspek keperilakuan terhadap sistem akuntansi di PT Sinar Galesong Prima di Manado. Untuk mengetahui pengaruh Sikap, Motivasi, Persepsi dan Emosi terhadap sistem akuntansi di PT Sinar Galesong Prima di Manado.

\section{TINJAUAN PUSTAKA}

\subsection{Pengertian Akuntansi}

Akuntansi adalah seni pencatatan, pengklasifikasian, dan pengikhtisaran transaksi dan peristiwa keuangan dengan cara tertentu dan dalam ukuran moneter, termasuk penafsiran atas hasil - hasilnya. Menurut Karl Marx (2001) dalam buku SIA bahawa Akuntansi merupakan bentuk kesadaran yang palsu dan merupakan alat untuk memastikan, bukan memberikan informasi yang benar tentang hubungan sosial yang membentuk lembaga produksi. Akuntansi merupakan suatu aktifitas jasa yang adalah untuk menyediakan informasi kuantitatif, terutama yang mempunyai sifat dalam pengambilan keputusan ekonomis dalam memberikan keputusan pilihan-pilihan yang logis diantara berbagai tindakan alternatif.

\subsection{Sistem Informasi Akuntansi Pengertian Sistem}

Menurut Sujarweni $(2015: 1)$ sistem adalah kumpulan elemen yang saling berkaitan dan bekerja sama dalam kumpulan melakukan kegiatan untuk mencapai suatu tujuan. Pengertian sistem dilihat dari masukan dan keluarannya. Sistem adalah suatu rangkaian yang berfungsi menerima input (masukan), mengolah input, dan menghasilkan output (keluaran). Sistem yang baik akan mampu bertahan dalam lingkungannya. Pengertian sistem dilihat dari prosedur/kegiatan yang dibuat untuk melaksanakan program perusahaan.

\section{Sistem Akuntansi}

Menurut Sujarweni (2015 : 3) akuntansi adalah proses dari transaksi yang dibutuhkan dengan faktur, lalu dari transaksi dibuat jurnal, buku besar, neraca lajur, kemudian akan menghasilkan informasi dalam bentuk laporan keuangan yang digunakan pihak-pihak tertentu.

\section{Sikap}

Sikap atau attitude oleh Kreitner dan kiniki di kutip oleh Wibowo (2014:90) didefinisikan sebagai suatu kecenderungan yang dipelajari untuk merespon dengan cara menyenangkan atau tidak menyenangkan secara konsisten berkenan dengan objek tertentu.

\section{Emosi}

Lubis (2010:103) mengatakan bahwa setiap orang memiliki karakteristik kepribadian, tetapi karakteristik kepribadian itu sering kita campur adukkan dengan sikap emosi kita.

\section{Motivasi}

Menurut Newston yang dikutip oleh Wibowo (2010:110), motivasi kerja adalah hasil dari kumpulan kekuatan internal dan eksternal yang menyebabkan pekerja memilih jalan bertindak yang sesuai dan menggunakan perilaku tertentu.

\section{Persepsi}

Persepsi merupakan proses menerima informasi dan membuat pengertian tentang dunia di sekitar kita menurut McShane dan Von glinow dikutip oleh Wibowo (2014:59), hal tersebut memerlukan pertimbangan informasi mana perlu diperhatikan bagaiman 
mengkategorikan informasi dan bagaimana menginterpretasikan dalam kerangka kerja pengetahuan kita yang telah ada. (Wibowo 2016:60).

\section{Kerangka Konseptual}

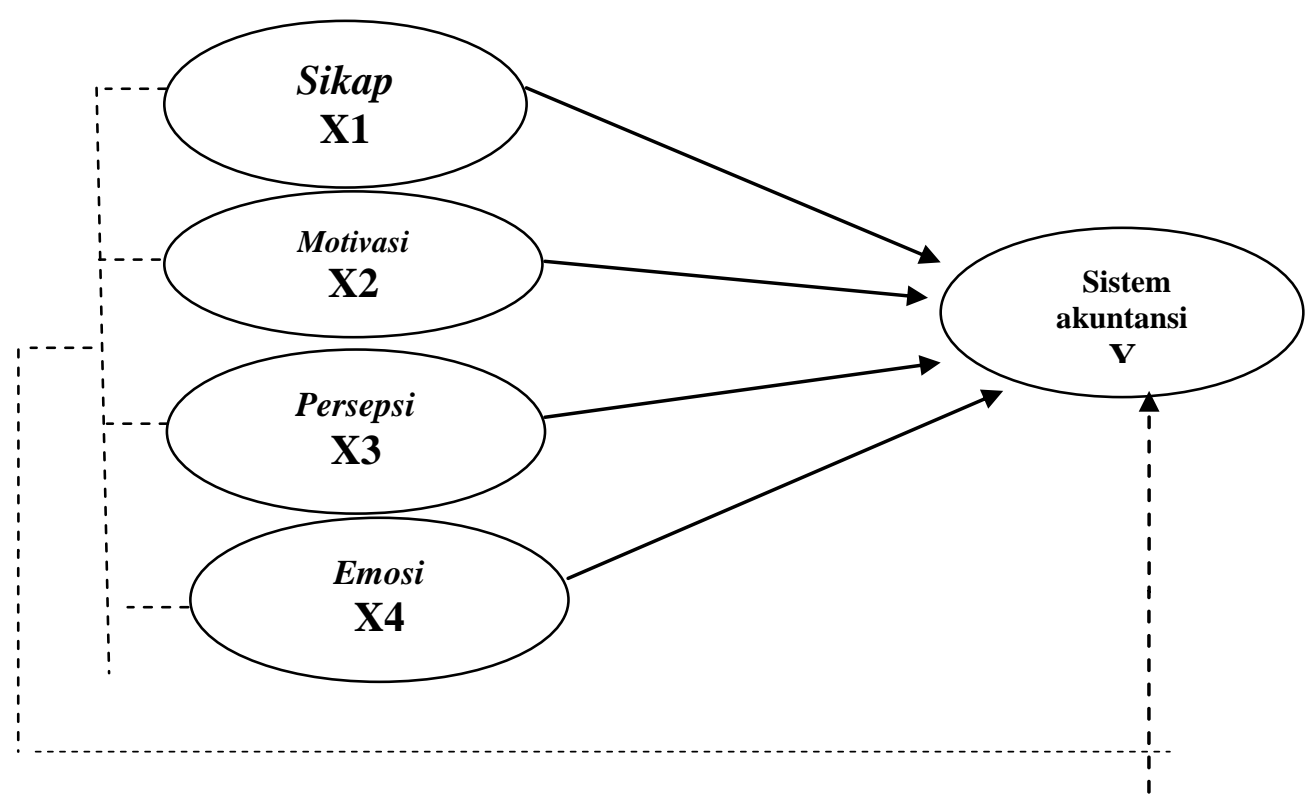

Gambar 2.6.1 Kerangka Konseptual Penelitian

\section{Hipotesis Penelitian}

Berdasarkan kajian teori dan kerangka konseptual penelitian, maka dirumuskan hipotesis adalah diduga Sikap, Motivasi, Persepsi, dan Emosi berpengaruh secara parsial terhadap jalannya sistem akuntansi dan Diduga Sikap, Motivasi, Persepsi, dan Emosi berpengaruh secara simultan terhadap jalannya sistem akuntansi.

\section{METODE PENELITIAN}

\section{Jenis Penelitian}

Jenis penelitian ini adalah penelitian asosiatif dengan metode deskriptif kuantitatif, yaitu menggambarkan data yang diperoleh dan menganalisis data yang ada secara kualitatif. Penelitian deskriptif meliputi penilaian sikap atau pendapat tarhadap individu, organisasi, keadaan, maupun prosedur. Data deskriptif pada umumnya dikumpulkan melalui daftar pertanyaan dalam survei, wawancara, ataupun observasi (Indrawan dan Yaniawati, 2014:56).

\section{Tempat dan Waktu Penelitian}

Penelitian ini dilaksanakan pada PT. Sinar Galesong Prima di Manado, yang bertempat di Jl. Piere Tendean No.9 Boulevard-Manado.

\section{Populasi dan Sampel}

Populasi dalam penelitian ini adalah seluruh pegawai PT.Sinar Galesong Prima di manado yang terdiri dari bagian akuntansi, administrasi dan gudang yang berjumlah (38) reponden berdasarkan dari instansi, tingkat pendidikan, umur, dan lama bekerja.

\section{Metode Pengumpulan Data}
1. Kuisioner
2. Wawancara
3. Observasi 


\section{Metode Analisis Data}

Metode analisis yang digunakan untuk membahas permasalahan dalam penelitian ini adalah analisis regresi linier berganda.

\section{Uji Validitas dan Realibilitas}

Uji validitas dan reabilitas merupakan poin penting dalam sebuah analisa data. Hal tersebut dilakukan untuk menguji apakah suatu alat ukur atau instrument penelitian (dalam hal ini data dari kuisioner) sudah valid dan realibel. Pengujian validitas digunakan dengan mengguankan cara mengkorelasikan antara skor masing-masing butir atau item pertanyaan dengan skor total yang diperoleh dari penjumlahan semua skor pertanyaan. Jika korelasi tersebut signifikan maka alat ukur yang digunakan mempunyai validitas.

\section{Analisis Regresi Linear Berganda}

Analisis regresi linear berganda pada dasarnya adalah studi mengenai ketergantungan variabel dependen (terikat) dengan satu atau lebih variable independen (bebas), dengan tujuan untuk pemecahan masalah penelitian.

\section{HASIL PENELITIAN DAN PEMBAHASAN \\ Hasil Penelitian Data \\ Uji Pengujian Validitas dan Reabilitas}

Tabel 4.5 Hasil Pengujian Validitas X1 (Sikap)

\begin{tabular}{cccc}
\hline Pertanyaan & $\begin{array}{c}\text { Pearson } \\
\text { Correlation }\end{array}$ & $\mathbf{r}_{\text {tabel }}$ & Keterangan \\
\hline P1 & $\mathbf{0 . 5 2 3}$ & $\mathbf{0 . 3 2 0}$ & Valid \\
\hline P2 & $\mathbf{0 . 5 7 5}$ & $\mathbf{0 . 3 2 0}$ & Valid \\
\hline P3 & $\mathbf{0 . 6 3 3}$ & $\mathbf{0 . 3 2 0}$ & Valid \\
\hline P4 & $\mathbf{0 . 6 5 8}$ & $\mathbf{0 . 3 2 0}$ & Valid \\
\hline & Sumber : Output pengolahan data SPSS 15.0 2017
\end{tabular}

Tabel 4.6 Hasil pengujian Reliabilitas Variabel X1 (Sikap)

CRONBACH'S ALPHA N OF ITEMS

0.781 4

Sumber : Output pengolahan data SPSS 15.0 2017

Tabel 4.7 Hasil Pengujian Validitas X2 (Motivasi)

\begin{tabular}{cccc}
\hline Pertanyaan & $\begin{array}{c}\text { Pearson } \\
\text { Correlation }\end{array}$ & $\mathbf{r}_{\text {tabel }}$ & Keterangan \\
\hline P1 & $\mathbf{0 . 7 6 1}$ & $\mathbf{0 . 3 2 0}$ & Valid \\
\hline P2 & $\mathbf{0 . 5 6 9}$ & $\mathbf{0 . 3 2 0}$ & Valid \\
\hline P3 & $\mathbf{0 . 7 0 6}$ & $\mathbf{0 . 3 2 0}$ & Valid \\
\hline P4 & $\mathbf{0 . 6 7 9}$ & $\mathbf{0 . 3 2 0}$ & Valid \\
\hline P5 & $\mathbf{0 . 6 3 6}$ & $\mathbf{0 . 3 2 0}$ & Valid \\
\hline & Sumber : Output pengolahan data SPSS 15.0 2017
\end{tabular}

Tabel 4.8 Hasil pengujian Reliabilitas Variabel (X2) Motivasi

Cronbach's Alpha

$\mathrm{N}$ of Items

0.762

5

Sumber : Output pengolahan data SPSS 15.0 2017 


\begin{tabular}{cccc}
\hline & \multicolumn{3}{c}{ Tabel 4.9 Hasil pengujian Validitas Variabel (X3) Persepsi } \\
\hline Pertanyaan & $\begin{array}{c}\text { Pearson } \\
\text { Correlation }\end{array}$ & $\mathbf{r}_{\text {tabel }}$ & Keterangan \\
& $\mathbf{0 . 5 1 1}$ & $\mathbf{0 . 3 2 0}$ & Valid \\
\hline P1 & $\mathbf{0 . 5 8 9}$ & $\mathbf{0 . 3 2 0}$ & Valid \\
\hline P2 & $\mathbf{0 . 7 3 3}$ & $\mathbf{0 . 3 2 0}$ & Valid \\
\hline P3 & $\mathbf{0 . 5 7 5}$ & $\mathbf{0 . 3 2 0}$ & Valid \\
\hline P4 & $\mathbf{0 . 5 5 2}$ & $\mathbf{0 . 3 2 0}$ & Valid \\
\hline P5 & Sumber : Output pengolahan data SPSS 15.02017
\end{tabular}

Tabel 4.10 Hasil pengujian Reliabilitas Variabel X3 (Persepsi)

\begin{tabular}{cccc}
\hline \multicolumn{2}{c}{ Cronbach's Alpha } & \multicolumn{2}{c}{ N of Items } \\
\hline \multicolumn{3}{c}{$\mathbf{0 . 8 1 5}$} & \multicolumn{2}{c}{$\mathbf{5}$} \\
\hline & \multicolumn{1}{c}{$\begin{array}{c}\text { Sumber : Output pengolahan data SPSS 15.0 2017 } \\
\text { Tabel 4.11 Hasil pengujian Validitas Variabel X4 (Emosi) }\end{array}$} \\
\hline Pertanyaan & $\begin{array}{c}\text { Pearson } \\
\text { Correlation }\end{array}$ & r $_{\text {tabel }}$ & Keterangan \\
& $\mathbf{0 . 7 2 4}$ & $\mathbf{0 . 3 2 0}$ & Valid \\
\hline P1 & $\mathbf{0 . 6 9 5}$ & $\mathbf{0 . 3 2 0}$ & Valid \\
\hline P2 & $\mathbf{0 . 0 8 9}$ & $\mathbf{0 . 3 2 0}$ & Tidak Valid \\
\hline P3 & $\mathbf{0 . 0 7 8}$ & $\mathbf{0 . 3 2 0}$ & Tidak Valid \\
\hline P4 & $\mathbf{0 . 0 0 6}$ & $\mathbf{0 . 3 2 0}$ & Tidak Valid \\
\hline P5 & Sumber : Output pengolahan data SPSS 15.0 2017
\end{tabular}

Tabel 4.12 Hasil pengujian Reliabilitas Variabel X4 (Emosi)

Cronbach's Alpha $\mathrm{N}$ of Items 0.707 2 Sumber : Output pengolahan data SPSS 15.02017

Tabel 4.13 Hasil pengujian Validitas Variabel Y (Sistem Akuntansi)

\begin{tabular}{cccc}
\hline Pertanyaan & $\begin{array}{c}\text { Pearson } \\
\text { Correlation }\end{array}$ & $\mathbf{r}_{\text {tabel }}$ & Keterangan \\
\hline P1 & $\mathbf{0 . 8 6 0}$ & $\mathbf{0 . 3 2 0}$ & Valid \\
\hline P2 & $\mathbf{0 . 9 1 2}$ & $\mathbf{0 . 3 2 0}$ & Valid \\
\hline P3 & $\mathbf{0 . 7 4 4}$ & $\mathbf{0 . 3 2 0}$ & Valid \\
\hline P4 & $\mathbf{0 . 6 2 9}$ & $\mathbf{0 . 3 2 0}$ & Valid \\
\hline P5 & $\mathbf{0 . 8 0 2}$ & $\mathbf{0 . 3 2 0}$ & Valid \\
\hline & Sumber : Output pengolahan data SPSS 15.0 2017
\end{tabular}

Tabel 4.14 Hasil pengujian Reliabilitas Variabel Y (Sistem Akuntansi) Cronbach's Alpha 0.843 $\mathrm{N}$ of Items 5 Sumber : Output pengolahan data SPSS 15.02017

Analisis Regresi Linear Berganda

Berdasarkan pengujian SPSS 2.1. maka persamaan regresi linear berganda dalam penelitian ini dapat dilihat pada Tabel di bawah ini. 
Tabel 4.18 Hasil Regresi Linear Berganda Coefficients $^{\mathrm{a}}$

\begin{tabular}{|c|c|c|c|c|c|c|c|}
\hline \multirow[t]{2}{*}{ Model } & \multicolumn{2}{|c|}{$\begin{array}{l}\text { Unstandardized } \\
\text { Coefficients }\end{array}$} & \multirow{2}{*}{$\begin{array}{c}\begin{array}{c}\text { Standardiz } \\
\text { ed }\end{array} \\
\text { Coefficient } \\
\text { s } \\
\text { Beta }\end{array}$} & \multirow[t]{2}{*}{$T$} & \multirow[t]{2}{*}{ Sig. } & \multicolumn{2}{|c|}{$\begin{array}{l}\text { Collinearity } \\
\text { Statistics }\end{array}$} \\
\hline & B & $\begin{array}{l}\text { Std. } \\
\text { Error }\end{array}$ & & & & $\begin{array}{c}\text { Toleranc } \\
\mathrm{e}\end{array}$ & VIF \\
\hline (Constant) & 20.227 & 5.289 & & 3.824 & 0.001 & & \\
\hline $\mathrm{X} 1$ & 0.200 & 0.384 & 0.128 & 0.522 & 0.605 & 0.495 & 2.020 \\
\hline $\mathrm{X} 2$ & 0.062 & 0.392 & 0.054 & 0.159 & 0.874 & 0.256 & 3.908 \\
\hline X3 & -0.011 & 0.249 & -0.010 & -0.044 & 0.965 & 0.592 & 1.688 \\
\hline X4 & -0.446 & 0.681 & -0.185 & -0.655 & 0.517 & 0.375 & 2.670 \\
\hline
\end{tabular}

Sumber : output pengolahan data SPSS 2,1 2017

Berdasarkan Tabel 4.18, maka hasil persamaan regresi linear berganda dirumuskan sebagai berikut.

$$
Y=20.227+0.200 X_{1}+0.062 X_{2}-0.011 X_{3}-0.446 X_{4}
$$

\section{Pembahasan}

Berdasarkan hasil penelitian yang didapatkan oleh penulis melalui kuesioner yang telah diuji dengan pengujian hipotesis dan uji statistik yang sesuai serta dengan mempelajari buku-buku dan literatur yang berkaitan dengan penelitian maka, dapat dijelaskan hasilnya melalui pembahasan berdasarkan masing-masing variabel yang diteliti yakni dari sisi sikap, motivasi, persepsi dan emosi yang dilaksanakan pada PT. Sinar Galesong Prima di Manado. Sikap tidak berpengaruh signifikansi secara statistik terhadap sistem akuntansi baik secara parsial dan simultan. Berdasarkan hasil penelitian hipotesis maka Sikap kurang berpengaruh signifikan sistem akuntansi yang ada di PT. Sinar Galesong Prima. Hal ini dikarena bahwa sikap karyawan di PT.Sinar Galesong Prima sudah baik dalam melaksanakan tugas dan tanggung jawab dan sesuai dengan waktu yang ditentukan. Motivasi tidak berpengaruh signifikansi secara statistik terhadap sistem akuntansi baik secara parsial dan simultan. Hal ini dikarena bahwa pemotivasian terhadap karyawan di PT. Sinar Galesong Prima yang sudah baik. Persepsi berpengaruh signifikan sistem akuntansi yang ada di PT. Sinar Galesong Prima. Hal ini dikarena bahwa cara berpikir dan cara pandang karyawan di PT.Sinar Galesong Prima yang masih belum baik. Emosi tidak berpengaruh signifikan sistem akuntansi yang ada di PT. Sinar Galesong Prima. Hal tersebut menggambarkan bahwa dalam melaksanakan tugas dan pekerjaan, karyawan cenderung tidak menujukan emosi yang baik itu perasaan ketika melakukan pekerjaan.

\section{PENUTUP}

\subsection{Kesimpulan}

Berdasarkan hasil pembahasan sebelumnya maka dapat ditarik kesimpulan sbahwa Sikap tidak berpengaruh secara signifikan terhadap sistem informasi akuntansi. Sikap karyawan tergolong sudah baik sehingga mereka melakukan pekerjaan sesuai dengan prosedur yang telah ditetapkan perusahaan. Motivasi tidak berpengaruh secara signifikan terhadap sistem informasi akuntansi sehingga manjemen perusahaan sudah dinilai baik dalam memotivasi karyawan baik dalam bentuk penghargaan atau upaya motivasi secara dukungan moral. Emosi tidak berpengaruh secara signifika terhadap sistem informasi akuntansi hal ini karena 
karyawan tidak menunjukan emosi dalam bekerja. Presepsi berpengaruh secara signifikan terhadap sistem informasi akuntansi hal ini disebabkan karena cara pandang karyawan serta tugas dan pekerjaan. Karyawan memandang tujuan dari perusahaan sebagai dasar melakukan suatu pekerjaan. Secara simultan aspek keperilakuan tidak berpengaruh signifikan terhadapa sistem informasi akuntansi di PT. Sinar Galesong Prima.

\subsection{Saran}

Berdasarkan hasil penelitian maka penulis mengajukan saran yang diharapkan dapat menjadi masukan yang berguna bagi pihak-pihak yang berkepentingan sebagai

1. Perlu untuk tetap menjaga peraturan yang mengatur sikap karyawan untuk kelancaran penerapan sistem informasi akuntansi.

2. Perlu menjaga adanya penghargaan untuk prestasi atau kinerja karyawan sehingga akan ada peningkatan dalam motivasi kerja karyawan.

\section{DAFTAR PUSTAKA}

Apriwandi, 2013 . Pengaruh Aspek Keperilakuan akuntansi manajemen terhadap kinerja manajer dalam partisipasi anggaran pada manajer rumah sakit sejawa tengah.Hhtp:/respository.widyatama.av/xmlui/bilstream/handle/123456/89 /3299/Ariwandi.pdf? sequence=2. Diakses pada tanggal 02 Februari 2017

Akay, 2016 Analisis Aspek Keperilakuan terhadap Penerapan Sistem Akuntansi Persediaan pada Pt. Surya Wenang Indah Manado. Jurnal EMBA Vol 4 No1. Ejournal.unsrat.ac.id/index.php/emba/article/view/11771 diakses pada tanggal 02 Februari 2017

Buku Panduan Penulisan Skripsi FEB Universitas Sam Ratulangi 2014.

Hudayati, 2002. Perkembangan Penelitian Akuntansi Keperilakuan Berbagai teori dan pendekatan yang melandasai. Diakses pada Tanggal 20 Februari 2017

Hermawan, 2009. Perilaku Informasi Akuntansi Manajemen Untuk Pengambilan Keputusan Dan Kinerja Manajerial. Jurnal Ekonomi Manajemen dan Akuntansi (EMISI), FE UMSIDA Vol 2 No 1. Diakses pada Tanggal 22 Februari 2017.

Hudayati, 2002. Perkembangan Penelitian Akuntansi Keperilakuan : Berbagai Teori dan Pendekatan yang Melandasi. JAAI Vol 6 No 2. Diakses pada Tanggal 22 Februari 2017.

Indriani dan Nardisya, 2015.Interaction effect of budgetary Participation and and management accounting system of managerial performance : Evidence of Indonesia.Global Journal of Journal Busines Research, VOL 9. Diakses pada Tanggal 22 Februari 2017.

Indrawan dan Yaniawati, 2014. Metodologi Penelitian. Refika Aditama. Jakarta.

Ikhsan A dan Ishak M, 2005. Akuntansi Keperilakuan. Salemba Empat, Jakarta.

Indriani dan Lulyta, 2008. Pengaruh Variabel Perilaku Karyawan Akuntansi Terhadap Kinerja Perusahaan (Studi empiris pada Perusahaan BUMN dan BUMD di Bnada Aceh). Vol 2 No. 1. Diakses pada 22 Februari 2017.

Janitra. 2015. Pengaruh Faktor Keperilakuan Organisasi terhadap Kegunaan Sistem Akuntansi Keuangan .hhtp://eprints.ums.ac.id/41533/1Naskah\%pulikasih.pdf. diakses pada tanggal 16 Februari 2017.

Kuang, Tan Se Tin. 2010. Analisis Perkembangan Riset Akuntansi Keperilakuan Studi Pada Jurnal Behavioral Research in Accounting (1998-2003). Jurnal $\begin{array}{lllll}\text { Akuntansi } & \text { Vol. } & 2 & \text { No. } & 2\end{array}$ http://majour.maranatha.edu/index.php/maksi/article/viiew/618. Diakses 
pada tanggal 02 Februari 2017.

Kim. C.K, 2005. Behavioural Accounting Study of Strategic interaction in a Tax Compliance gam.Hhtp://ww.springer.com/eda/content/document/cda_downloaddocume nt/9780387242156-c2,pdf?SGWID0-0-45-369507-.

Kusuma, 2003. Penelitian Akuntansi Keperilakuan Dalam Jurnal Behavioral Research In Accounting (BRIA). Jurnal Bisnis dan Akuntansi Vol 5 No. 2 Diakses pada Tanggal 22 Februari 2017.

Kim, 2005. A Behavioral Accounting Study Of Strategic Interaction In a Tax Compliance Game. Experimental Business Research. Vol 3. Diakses pada Tanggal 22 Februari 2017.

L,M Samryn, 2010. Pengantar Akuntansi buku2 (Metode Akuntansi untuk Elemen Laporan Keuangan). Penerbit Andi Yogyakarta, Yogyakarta.

Littleton,Muhammad, 2002.http://Wikipedia/2010/03/definisi-akuntansi-menurutpara-ahli.htm1 diakses pada tanggal 02 Februari2017.

Lindawati, dan Irma Salamah, 2012. Pemanfaatan Sistem Informasi dan Teknologi Informasi Pengaruhnya Terhadap Kinerja Individual Karyawan. Jurnal $\begin{array}{llllll}\text { Akuntansi dan Keuangan } & \text { Vol. } 14 & \text { No. } & 1\end{array}$ http://Jurnalakuntansi.petra.ac.id/index.php/aku/article/view/18633/18395. Diakses pada tanggal 02 Februari 2017.

Loord dan Zoort, 1997. Teori Keperilakuan. Hhtp://diglib.mercubuana.ac.id/. diakses pada tanggal 1 oktober.

Lubis, Arfan Ikhsan, 2010. Akuntansi Keperilakuan. Salembra Empat Jakarta.

Mujilan, 2012. Sistem Informasi Akuntansi. Penerbit Pustaka Baru Press, Yogyakarta

Mirani, 2011. Faktor Keperilakuan organisasi terhadap kegunaan sistem akuntansi keuangan daerah dengan konflik kognitif dan konflik afektif sebagai intervening. Diakses pada Tanggal 22 Februari 2017.

Muliawati, 2012. Aspek Keperilakuan dalam Akuntansi Keuangan. Vol 16 No 2. Diakses pada Tanggal 22 Februari 2017

Niswatin, 2012. Dimensi Keperilakuan dari Pengganggaran Partisipatif. Jurnal Bisnis dan Akuntansi. Diakses pada Tanggal 22 Februari 2017.

Priyatno, Duwi. 2013. Analisis korelasi, Regresi, dan Multivariate dengan SPSS. Gava Media, Yogyakarta 